PUHEENJOHTAJAN KATSAUS

\title{
Puheenjohtajan katsaus vuoteen 2018
}

\author{
Noora Hirvonen \\ Informaatiotutkimus, Oulun yliopisto \\ noora.hirvonen@oulu.fi \\ https://orcid.org/0000-0001-7577-3057
}

Avainsanat: informaatiotutkimus; seminaarit; tieteellinen julkaisutoiminta; tieteelliset seurat

Vuonna 2018 Informaatiotutkimuksen yhdistyksen toiminnassa näkyivät erityisesti avoimen tieteen ja koulutuksen teemat sekä uudenlainen yhteistyö.

Yhdistys toteutti yhdessä Kulttuurintutkimuksen seuran kanssa hankkeen, jossa selvitettiin avointa vertaisarviointia Suomessa. Rahoitusta hankkeelle saimme Suomen tiedekustantajien liitolta ja sen myötä yhdistyksellä oli myös ensimmäistä kertaa palkattu työntekijä. Selvityksen ideoi ja rahoituksen sille hankki työryhmä, johon kuuluivat Mikael Laakso, Susanna Nykyri ja Riitta Koikkalainen. Hankkeen tavoitteena oli saada tietoa avoimeen vertaisarviointiin liittyvistä asenteista ja suunnitelmista suomalaisen tiedejulkaisemisen kentällä ja laatia lehdille konkreettisia malleja avoimeen vertaisarviointiin. Selvityksen kohderyhmiä ovat suomalaisten tieteellisten Artikkeli on lisensoitu Creative Commons Nimeä-EiKaupallinen-JaaSamoin 4.o Kansainvälinen -lisenssillä 
lehtien ja kirjankustantajien toimituskunnat, kirjoittajat ja vertaisarvioijat. Hankkeen taustoja kuvataan Informaatiotutkimus-lehden vuoden 2018 ensimmäisessä numerossa (Jytilä, Koikkalainen, Laakso \& Nykyri 2018) ja sen tuloksia on avattu maaliskuussa julkaistussa raportissa (Jytilä \& Laakso 2019).

Kevätseminaarimme Avoin julkaiseminen osana avointa tiedettä järjestettiin toukokuussa 2018 Hankenilla Helsingissä. Seminaarissa kuultiin avoimen vertaisarvioinnin hankkeesta ja käsiteltiin avointa julkaisutoimintaa tieteellisten kirjastojen ja tiedelehtien näkökulmasta. Hankenilla tietojenkäsittelytieteen yliopistonlehtorina työskentelevä, avoimen tieteen asiantuntija Mikael Laakso puhui avoimen julkaisemisen kysymyksistä yleisellä tasolla. Avoimen vertaisarvioinnin hankkeessa tutkijana työskennellyt Riitta Jytilä esitteli hankkeen taustaa ja alustavia tuloksia. Informaatiotutkimuslehden päätoimittaja, Tampereen teknillisen yliopiston kirjaston johtava tietoasiantuntija Susanna Nykyri pohti esityksessään avoimen julkaisemisen kysymyksiä Informaatiotutkimus-lehden perspektiivistä. Pitkän uran Kulttuurintutkimus-lehden päätoimittajana tehnyt, Kansalliskirjaston tietoasiantuntija Riitta Koikkalainen käsitteli teemaa Kulttuurintutkimuksen näkökulmasta. Lisäksi kuultiin yliopistokirjastojen avoimeen julkaisemisen ja sen tukipalvelujen käytäntöjä: Katja Fält (Tampereen teknillisen yliopiston kirjasto) esitteli FAIR data -periaatteita ja Markku Roinila (Helsingin yliopiston kirjasto) avoimen tieteen tutkijapalveluita Helsingin yliopistossa.

Informaatiotutkimus-lehdessä julkaistiin Avoin tiede ja avoin tieto -teemanumero (4/2018), jonka vierailevana päätoimittajana toimi Mikael Laakso. Numero sisältää myös tutkimuksen arvioinnin käytäntöihin kohdistuvan DORA-julistuksen (Nykyri 2018) suomennoksen.

Avoimuuden teemaan kytkeytyi myös toukokuussa voimaan astunut EU:n yleinen tietosuoja-asetus (GDPR, General Data Protection Regulation), jonka tavoitteena on lisätä läpinäkyvyyttä ja varmistaa, että henkilötietoja käytetään asianmukaisesti. Yhdistyksemme tarkisti henkilötietojen käsittelyyn liittyviä prosessejaan varmistaakseen, että tietosuoja-asetuksen vaatimukset täyttyvät.

Syyskuussa yhdistys osallistui Oulussa järjestettyyn kansainväliseen European Conference on Information Literacy (ECIL) -konferenssiin organisoimalla tieteelliseen kirjoittamiseen keskittyvän tohtorifoorumin. Myös tähän saimme tukea Suomen tiedekustantajien liitolta. Forumiin osallistui 15 tohtorikoulutettavaa ja siinä puhuivat Journal of Information Literacy -julkaisun päätoimittaja, tutkija Emma Coonan (Anglia Ruskin University, UK) ja professori Peter Bath (University of Sheffield, UK). Tohtorikoulutettavia mentoroivat heidän lisäkseen kokeneet tutkijat Karen Fisher, Sirje 
Virkus, Serap Kurbanoğlu, Sonja Špiranec sekä Anna Suorsa ja Heidi Enwald yhdistyksestämme. Minä toimin forumin puheenjohtajana. Konferenssin teema tullee näkymään Informaatiotutkimus-lehdessä informaatiolukutaitoon liittyvinä kirjoituksina.

Syksyllä yhdistys viritteli yhteistyötä Suomen Tieteellisten Kirjastojen Seuran (STKS) kanssa. Nyt STKS:n jäsenet pääsevät järjestämiimme koulutustilaisuuksiin jäsenhintaan ja vastaavasti yhdistyksemme jäsenet voivat osallistua STKS:n koulutuksiin heidän jäsenhinnallaan.

Marraskuussa järjestimme Informaatiotutkimuksen päivät Åbo Akademissa Turussa. Päivillä kuultiin kahta kutsuttua puhujaa (Mats Neovius ja Shahrokh Nikou) ja järjestettiin kahdeksan alan tutkimusta käsittelevää työryhmää: 1. Humanismi ja informaatiotutkimus (puheenjohtajina Vesa Suominen, Pirjo Tuomi ja Jarmo Saarti), 2. Knowledge Management (emerging trends) (puheenjohtajina Anna Suorsa ja Farhan Ahmad), 3. Internetin lieveilmiöt ja verkon vaarat (puheenjohtajina Ari Haasio ja Anu Ojaranta), 4. Informaatiotutkimuksen väitöskirjahankkeet (puheenjohtajina Elina Late ja Sanna Kumpulainen), 5. Terveystietoja e-terveys (puheenjohtajina Isto Huvila ja HIBA-hanke), 6. Avoin tiede ja avoin tieto (puheenjohtajina Mikael Laakso ja Susanna Nykyri), 7. Erilaiset lukutaidot ja lukuharrastuksen monimuotoinen tukeminen (puheenjohtajina Anu Ojaranta ja Siinamari Tikkinen) ja 8. Information behaviour and information practices among minorities (puheenjohtajina Jannica Heinström, Eeva-Liisa Eskola ja Hilda Ruokolainen). Näiden lisäksi organisoitiin kaksi alan koulutukseen keskittyvää työryhmää. Toinen käsitteli yleisten kirjastojen osaamisvaatimuksia ja koulutuksen vastaavuutta (puheenjohtajana Ari Haasio), toinen informaatioalan yliopistokoulutusta ja työelämätarpeita (puheenjohtajina Noora Hirvonen ja Susanna Nykyri). Edellisen syksyn seminaarin teemaa jatkaneet työryhmät osoittivat, että koulutukseen liittyvälle keskustelulle on tarvetta. Informaatiotutkimuksen päivien esitysten laajennetut abstraktit löytyvät Informaatiotutkimus-lehden numerosta 3/2018.

Vuoden 2018 Informaatiotutkimus-lehden artikkelit löytyvät ainoastaan verkkojulkaisusta, sillä päätimme luopua painetusta vuosikirjasta. Viimeinen painettu vuosikirja ilmestyi vuonna 2018 ja siihen koottiin vuonna 2017 lehdessä julkaistut artikkelit. Informaatiotutkimus on ilmestynyt avoimena verkkojulkaisuna jo kymmenen vuoden ajan. Sen rinnalla julkaistun painetun vuosikirjan tilausmäärät ovat vuosi vuodelta vähentyneet. Samaan aikaan lehden aineistotarjonta ja verkkolukijoiden määrä on kasvanut merkittävästi. Vuosikirja teetti paljon työtä, josta toimivien rahoitusmallien puuttuessa emme voineet maksaa lehden tekijöille asianmukaista korvausta. Näimme siis parhaaksi, että pieni yhdistyksemme 
keskittyy verkkojulkaisun kehittämiseen ja luopuu vuosikirjan painattamisesta. Informaatiotutkimus on edelleen informaatiotutkimuksen alan ainoa kotimainen vertaisarvioitu, tieteellinen julkaisu ja toteuttaa avoimen tieteen periaatteita tarjoamalla julkaisun luettavaksi maksutta ja kaikille avoimesti.

Tähän toiminnantäyteiseen vuoteen on hyvä päättää toinen ja viimeinen kauteni Informaatiotutkimuksen yhdistyksen (ITY ry) puheenjohtajana. Kiitän yhdistyksen hallitusta ja jäseniä sekä Informaatiotutkimus-lehden toimitusta luottamuksesta ja toivotan lämpimästi tervetulleeksi yhdistyksen uuden puheenjohtajan Elina Laten. Jatkan edelleen hallituksen varajäsenenä ja tammikuusta 2019 alkaen toimin Informaatiotutkimus-lehden toimituskunnassa. Tapaamiisiin!

Ex-pj Noora Hirvonen

\section{Lähteet}

Jytilä, R., Koikkalainen, R., Laakso, M., \& Nykyri, S. (2018). Avointa vertaisarviointia koskevalle selvitykselle rahoitus. Informaatiotutkimus, 37(1). https://doi.org/10.23978/inf.70172

Jytilä, R. \& Laakso, M. (2019). Selvitys avoimesta vertaisarvioinnista kotimaisen tiedejulkaisemisen kentällä. Tieteellisten seurain valtuuskunnan verkkojulkaisuja 5. https://doi. org/10.23847/978-952-599516-9

Nykyri, S. (2018). DORA-julistus (San Francisco Declaration on Research Assessment). Informaatiotutkimus, 37(4). https://doi.org/10.23978/inf.77417 